\section{Oman Pangea Symposium and Fieldmeeting}

\author{
Muscat, Sultanate of Oman, 7-20 January, 2001
}

The Pangea Project is a research program sponsored by the IUGS Commission on Global Sedimentary Geology (GSGP), which was officially launched in a Workshop held in May 1992 in Lawrence, Kansas, USA. It was then decided that Project Pangea would focus on the most recent time of super-continent accretion and dispersal, i.e., from the Carboniferous to the Jurassic, when continents merged toward a geoid low, and much of Pangea's climate appeared to be disposed in an icehouse mode. Numerous international activities (workshops, symposia, and conventions) have been organised under the umbrella of the Pangea projects over the years, and have resulted in the publication of conference proceedings (5 until now). The preparation of the International Conference on the Geology of Oman organised by the Oman Ministry of Commerce and Industry, in cooperation with Sultan Qaboos University and the Mineralogical Institute of Bern University, was a unique opportunity for a Pangea Symposium proposal in this part of the world. This was done in 1999 by A. Baud and J. Marcoux, and was accepted the same year by the Organising Committee.

With the presentation of new and recent results on Permian and Triassic sediments of Oman, the aim of the Symposium and the Fieldmeetings was to provide a forum to geologists who are interested in the Pangean time interval for discussing global changes related to Pangea integration and North Gondwana and Central Tethys evolution. Members of the International Subcommissions on Permian and on Triassic Stratigraphy were also invited. For petrographers and geochemists, Oman is a key area for the study of the magmatism linked with the Permian Neotethys opening and with the Triassic intra-oceanic seamounts. Sedimentologists, stratigraphers and paleontologists working within the Permian and Triassic time interval and interested by topics as diverse as biotic crisis, extinction, recovery and evolution across the Palaeozoic-Mesozoic transition used the opportunity to discuss, observe and sample the spectacular Permian and Triassic outcrops of Oman's former continental margin, from shallow shelf to deep marine sediments and seamounts, and to participate in the Pangea Symposium

\section{Pre-Conference Excursions}

Two field excursions were organised before the Conference.

The theme of the Pre-Conference Excursion No. A01, from January 8-11, 2001, was "Permo-Triassic deposits, from and Triassic times. shallow platform to basin and seamounts". It was led by A. Baud, F. Bechennec, L. Krystyn, J. Marcoux R. Maury and S. Richoz. Sixteen participants attended this field trip with great interest and took part in the lively discussions on the outcrops. Firstly, the geology of the belt located in the eastern part of the Arabian Peninsula, the Oman Mountains was introduced. Briefly following a lower Permian rifting phase and middle Permian break-up (birth of the Neotethys), a wide carbonate platform developed during late Permian and Triassic times on the inner part of the margin. Carbonates derived from the platform represented the major source for the thick sequence of slope carbonates deposited near the platform margin. In the more distal areas, basinal and oceanic sedimentation resulted in various types of carbonate, chert and siliciclastic deposits, presently found in the Hawasina Nappe. Middle Permian radiolarites and red ammonoid limestones as Middle Triassic black marls and limestones deposited on lavas (seamounts) are cropping out on both sides of the "autochthonous" tectonic window as blocks of various dimensions, the Oman Exotics. New results on Permian and Triassic magmatism were also presented.

Spectacular and recently studied outcrops in Djebel Akhdar, Rustaq, Wadi Wasit, Ba'id, Musjah, Aq Quil, Jebel Kawr and Misfah areas allowed to reconstruct the former geometry of the margin during Late Permian

The theme of the Pre-Conference Excursion No. A02, from January 7-11, 2001 was "Lower to Middle Permian Sedimentation on the Arabian Platform in the

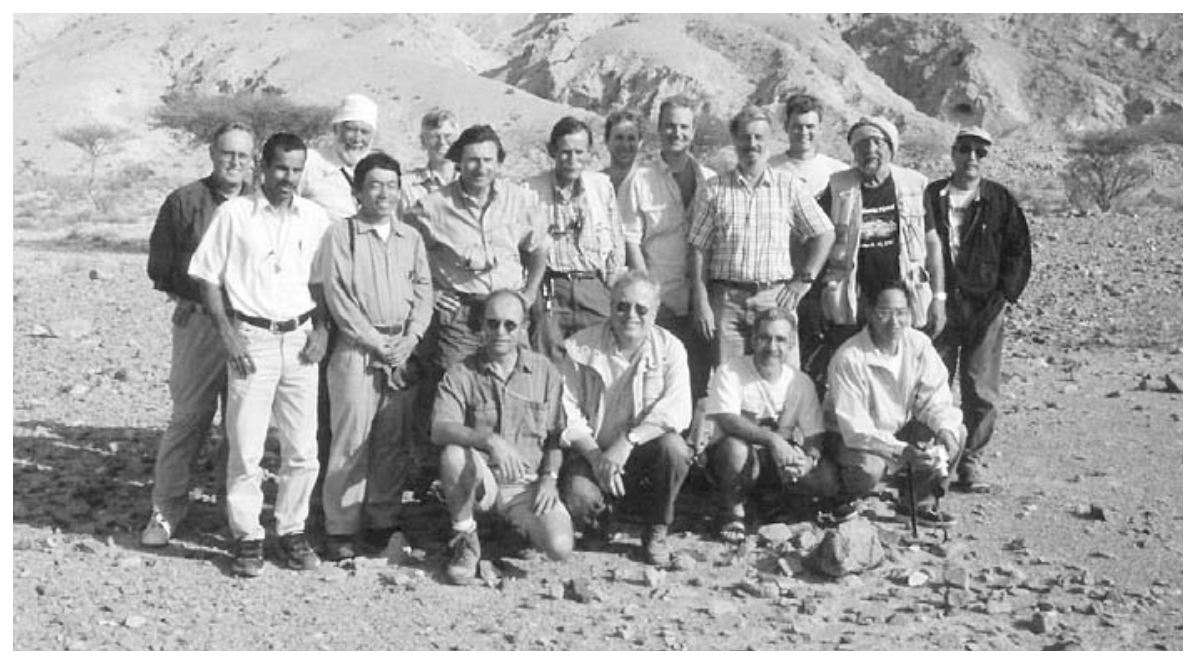

Figure 1 Participants and co-leaders of Pangea Excursion B0I with the Sumeini Range (Permian to Cretaceous slope deposits) in the foreground.
Huqf Area (S. Central Oman) and the Jebel Akhdar (Oman Mountains)". It was led by L. Angiolini, A. Nicora, J.-P. Platel and J. Roger, attended by 14 participants. This excursion provided the opportunity to see and sample the Peri-Gondwanan Permian succession of the Sultanate of Oman. Against the spectacular background of mountains and desert, different faunal and floral associations and depositional environments from platform to shallow basin were shown.

Starting in the desert of the interior Oman, the excursion visited the Huqf area, a region marked by gently deformed and uplifted Palaeozoic formations. Here, the Early to Middle Permian is represented by two mega-sequences separated by a regional unconformity, recording two major transgressive events respectively controlled by the last phase of the Gondwanan deglaciation and by the opening of the Neotethys. The first sequence consists of Lower Permian glaciolacustrine deposits of the Al Khlata Formation succeeded by the transgressive marine deposits of the Saiwan Formation, marking the complete deglaciation of the region. The latter unit, of late Sakmarian age, yields a rich and well-preserved brachiopod studied by $\mathrm{L}$. Angiolini, in addition to bivalve, gastropod, crinoid and bryozoan fauna.

Resting unconformably, the upper sequence is composed at the base of a thick fluvial terrigenous unit, the Gharif Formation. This sequence terminates with the highly fossiliferous transgressive marls and bioclastic limestones of the Khuff Formation containing brachiopods, conodonts, ostracodes (studied respectively by L. Angiolini, A. Nicora \& S. Crasquin), in addition to bivalves, gastropods, cephalopods and trilobites. Only the Wordian part is exposed below the angular unconformity of the Triassic continental Minjur Formation in the studied outcrops.

The Huqf succession represents a keysection for the intercalibration of Early to Middle Permian marine and continental biostratigraphical scales. In fact, if on one hand the fauna shows a marked transitional character, 
being represented by cosmopolitan, Gondwanan, Tethyan and endemic taxa, on the other the newly named Gharif Paleoflora (J. Broutin) is erected as a standard for the Arabian Peninsula. This warm humid assemblage is of outstanding palaeogeographic significance, because it comprises associated Gondwanan, Cathaysian and Laurasian floral elements.

Moving to the Oman Mountains, this excursion examined, together with Excursion A01, the Permian succession cropping out in the northwestern part of the Jebel Akhdar window, along the Wadi Sahtan. Here, the Permian is represented by the Wordian marine Saiq Formation, lying with a spectacular angular unconformity on the Proterozoic-Lower Paleozoic autochthon series. The Saiq Formation consists of conglomerates at the base overlain by bioclastic limestones and reef limestones, which are capped by dolomites. This unit marks the transgression on the newly formed Neotethyan margin.

\section{Pangea Symposium}

Between January 12-16, 2001, the conference on the geology of Oman attracted about 400 scientists from all over the world. As part of the conference, the 2-day Pangea Symposium started on January 14, in which 18 oral communications and 5 posters were presented. In their introduction, A. Baud and B. Beauchamp stated the general purposes of the Pangea Project and emphasised international cooperation. The main items of scientific progresses are summarised as follows.

\section{Stratigraphy and depositional models of the Permian and Triassic sediments in Oman}

A series of presentations on new results on the Permian and Triassic stratigraphy and correlations were given by Angiolini, L., Balini, M., Garzanti, E., Nicora, A. and Tintori, A. (The Gondwanan deglaciation in central Oman: paleontological and sedimentological evidence), Broutin, J., Berthelin, M. and Crasquin-Soleau, S. (The Permian 'Gharif paleoflora' and the ostracodes from the Khuff Formation, Huqf area, Sultanate of Oman), Archbold, N.W. (Oman to western Australia: Correlation of the Peripheral Gondwanan Permian), Bernecker, M. (Second-order cycle development of the Arabian platform and Hawasina seamounts: Permian and Triassic outcrop data from central Oman), Cordey, F., Baud, A., Béchennec, F., Gorican, S. Krystyn, L. and Robin C. (Permian-Triassic deep water sediments of the Wadi Wasit revisited).

Recent isotope studies were presented by Richoz, S., Atudorei, V., Baud, A. and Marcoux, J. (Upper Permian to lower Triassic carbon isotope record: review and new data in the Oman Mountains, from the shallow platform to the basin) and Richoz, S., Baud, A., Marcoux, J. and Cordey, F. (Lower Triassic carbon isotope stratigraphy of the Sumeini slope deposits, Maqam C, NW Oman).

New data on Permian-Triassic boundary were the subject of a talk by Baud, A., Cordey, F., Krystyn, L.Marcoux, J. and
Richoz, S. (The Permian-Triassic boundary in Oman, a review) and of a poster by Krystyn, L., Richoz, S. and Baud, A. (A unique Permian-Triassic boundary section from Oman). This is the first discovery of a completely dated Griesbachian coquinite limestone succession in Oman. This facies is unknown in other parts of the Tethys.

\section{Pangea paleoclimates, stratigraphy, magnetic} insight and palynofacies

The first presentation was given by MacDonald, W. and Ellwood, B. on Magnetic Insights into Permo-Triassic Pangea.

Late Permian cooling followed by a global warming was the subject of Beauchamp, B. and Baud, A. in "Demise of Permian biogenic chert along the margins of NW Pangea, Western Tethys and Gondwana: evidence for paleoceanographic disruption and global warming", and a late Permian warming was presented by Wopfner, H. (Late Palaeozoic to Early Triassic climatic transition between Africa and the Southern Alps).

Stratigraphy of Permian or Triassic sediments was presented by Jin Yugan (Lopingian), Bachmann, G.H., Brueckner-Roehling, S., Exner, M., Kedzierski, J. and Szurlies, M. (Sequence stratigraphy of the ScythianAnisian transgression, Triassic type region, Germany), Mandl, G.W. (From Triassic sea to Cretaceous orogen-The Austroalpine sector of the Tethyan shelf, Eastern Alps, Austria), Kozur, H.W. (Ladinian and Carnian palaeogeography of southern Turkey and its importance for the development of the Triassic Tethyan faunal provinces).

Sedimentology, correlations, paleoecology and palynology of the Permian-Triassic boundary interval were the subject of 4 presentations: - Brookfield, M. (Sedimentology of the Permo-Triassic boundary sections in Kashmir, India),-Twitchett, R.J. (High resolution, global correlation of the PermianTriassic interval),-Twitchett, R.J. and Looy, C.V. (Rapid and synchronous collapse of end-Permian marine and terrestrial ecosystems),-Spina, A., Cirilli, S and Baud, A. (Palynology of the uppermost Permianbasal Triassic successions in the High Arctic, Canada and comparison with some PTB Gondwanian localities).

All the abstracts of the Pangea Symposium are available on the Web at http://www.geoconfoman.unibe.ch/

\section{Post-Conference Excursion}

The Symposium was followed on January 17 by a 4-day Post-Conference Excursion (B01) on "Permo-Triassic deposits from shallow water to base of slope and basin", led by A. Baud, F. Bechennec, F. Cordey, J. Marcoux, R. Maury, J. le Metour and S. Richoz.

The Oman Mountains display a segment of the Gondwanian margin, interpreted as a flexural upper plate. The Permian-Triassic sequence deposited on the inner part of this margin is exceptionally well exposed in the Saih Hatat Mountains, as part of the "autochthonous" which crops out in a large tectonic window. The Permian and Triassic shallow water carbonate rocks occurring in this area belong to the Saiq and Mahil Formations. This was the subject of the first day trip. The Saiq Formation, about $400 \mathrm{~m}$ thick, consists of transgressive-regressive cycles of shallow carbonate and lava flows unconformably overlying Precambrian to Ordovician strata and documenting the upper Permian marine transgression and rift opening. The following Triassic dolomitic Mahil Formation confirms the cyclic and restricted shallow marine environment upward.

During the second day, the participants examined the basinal and oceanic sedimentation with the middle Permian red ammonoids limestones of Rustaq. The radiolarites of Buday'ah also deposited on lavas, cropping out as slices of various dimensions.

Carbonates derived from the platform represented the major source for the thick sequence of slope carbonates (the Sumeini Group) deposited near the platform margin, cropping out in the Sumeini area near the border between Oman and the United Arab Emirates. The lower part of this group (about $1700 \mathrm{~m}$ thick) is included in the Maqam Formation, late Permian to late Triassic in age. Key section of the Oman margin architecture, the Wadi Maqam was re-investigated in terms of biochronology, sequence and isotope stratigraphy: this was the subject of the third and the fourth days of the excursion.

Thanks to the Organising Committee in Muscat, to the Sultan Qaboos University, to the Oman Ministry of Commerce and Industry, and particulary to Dr. Hilal bin Mohammed Al-Azri, Director General of Minerals and to Prof. Peters and his collaborators in Bern. All of them made great efforts for the complete success of the conference and the excursions.

\section{Aymon Baud}

Chairman of the IUGS Commission on

Global Sedimentary Geology (GSGP)

Co-leader of the Oman Pangea Symposium and Fieldmeeting

Director of the Geological Museum,

BFSH2-UNIL

CH-1015 Lausanne

SWITZERLAND

E-mail:aymon.baud@sst.unil.ch

\section{Jean Marcoux}

Co-leader of the Oman Pangea Symposium and Fieldmeeting

Professor at Paris VII University

Sciences physiques de la terre

Pl. Jussieu 2

F-75251 Paris Cedex 05

FRANCE

E-mail: marcoux@ipgp.jussieu.fr

\section{Benoit Beauchamp}

Past Chairman of GSGP

Geological Survey of Canada

3303, 33rd Street NW

Calgary, Alberta T2L $2 A 7$

CANADA

E-mail: BBeaucha@NRCan.gc.ca 